Jurnal IImu Teknik Elektro Komputer dan Informatika (JITEKI)

Vol. 3, No. 2, Desember 2017

\title{
Performance Analysis of Hybrid Power Plant (Wind and Solar) in Baron Techno Park Gunung Kidul Yogyakarta
}

\author{
Mychel Gatriser Pae ${ }^{1}$, Ridwan Budi Prasetyo ${ }^{2}$, Suharyanto ${ }^{3}, \mathrm{~T}$. Haryono ${ }^{4}$ \\ Department of Electrical Engineering and Information Technology, Universitas Gadjah Mada ${ }^{1,3,4}$ \\ Agency Assessment and Application of Technology Yogyakarta ${ }^{2}$ \\ Jl. Grafika No.2, Yogyakarta ${ }^{1,3,4}$ \\ Kanigoro, Sapto Sari, District of Gunung Kidul, Daerah Istimewa Yogyakarta ${ }^{2}$ \\ mychel.pae@mail.ugm.ac.id'1 , ridwan.budi@bppt.go.id², suharyanto@ugm.ac.id ${ }^{3}$, \\ thr@ugm.ac.id ${ }^{4}$
}

\begin{abstract}
Renewable energy is generated through the conversion process of energy sources which are abundant in the earth such as wind, sun, heat, rain, geothermal, hydro, ocean water and others into an environmentally friendly form of energy. This kind of energy does not cause negative effects to the environment when being used. Therefore, by using renewable energy, the earth is not polluted. This is a major step in controlling global warming, which is one of the elements that leads to environmental degradation. The use of renewable energy sources is indispensable. One great opportunity for future renewable energy is the integration of various sources of energy (hybrid power plant). This paper presents the analysis performance of hybrid power plant (wind and solar) installed in the area of Baron Techno Park. Modeling with HOMER (Hybrid Optimization Model for Electric Renewable) Version 3.8.1 was done with two conditions, first was a grid connected and the second was an off-grid condition. The first system modeling for the installed system capacity NPC and COE had the lowest price for the off-grid condition being $\$ 62.020$ and - \$ 0.0213. For the \$ 4,910.37 / year was system operating cost. For this capacity, electricity that was connected into grid up to $152.473 \mathrm{kWh} /$ year. The second modeling systems was done with generating capacity in operating. Unknown NPC price was $\$ 20,887.76$ and the COE was - \$0,021 for grid connected system condition. Operational cost up to $\$ 1,685.87$ / year, and electricity production being was $63,55 \mathrm{kWh} /$ year. With the grid, the contribution of Baron Techno Park hybrid power plants could lower carbon dioxide gas up to $82.63 \mathrm{~kg} / \mathrm{year}$ for operating systems and $202.63 \mathrm{~kg} /$ year for systems with installed capacity.
\end{abstract}

Keywords: Wind; Solar; Hybrid; Homer; On-grid; Off-grid; NPC; COE.

\section{Introduction}

Availability of conventional energy sources in the earth is getting decreased day by day. it will bring an impact on the energy crisis if there are no suitable and sustainable solutions [1]. Renewable energy sources are an alternative energy solution to overcome dependence on electrical energy is to convert from conventional power plants such as coal and petroleum in Indonesia [2].

Special Region of Yogyakarta is one of 33 provinces in Indonesia, located in the central part of Java island. The southern part of Yogyakarta is restricted Indonesian seas, while the eastern part of northwest-southeast, west, and northwest bounded by the province of Central Java. The position of Yogyakarta Region, located between 70.33'- 80.12' south latitude and 1100.00 '1100.50' East Longitude, has an area of $3185.80 \mathrm{~km} 2$ recorded or $0: 17 \%$ of the area of Indonesia consisting of Kulon Progo district with an area of $586.27 \mathrm{~km} 2(18: 40 \%)$, Bantul with an area of $506.85 \mathrm{~km} 2(15.91 \%)$, Gunung Kidul with an area of $1485.36 \mathrm{~km} 2(46.63 \%)$, Sleman district with an area of $574.82 \mathrm{~km} 2(18.0 \%)$, and Yogyakarta city with an area of $32.50 \mathrm{~km} 2(1: 02 \%)$ [3].

As counties that have the largest area in Yogyakarta, Gunung Kidul district has a lot of potential the renewable energy includes wind energy potential, solar energy, sea etc. By used optimally, it will greatly impact on the lives of people in the area. This is the reason of the Agency for the Assessment and Application of Technology to develop some of the renewable energy and 
one of them is a hybrid power plant which is located in Kanigoro village, District Saptosari Gunung Kidul district Yogyakarta. Since 2010, BPPT has built "Baron Techno Park" as a center for research and development of renewable energy technologies, also used as dissemination of Science and Technology of Renewable Energy [4].

Baron Techno Park power plant system consists of two wind power plants with the capacity of $10 \mathrm{~kW}$ and $5 \mathrm{~kW}$. Solar power plants with the capacity of $36 \mathrm{~kW}$ are divided into three PV arrays with 120 cells of each array, system storage (Bank Battery) are divided into two arrays with 8 strings of each array, the capacity of bank Battery is 288 kVAh, 1200 Ah. Caused by some problems, until now system of a hybrid power plant that operated only a wind power plant with a capacity of $5 \mathrm{~kW}$ and solar power generation $24 \mathrm{~kW}$ [5]. Baron Techno Park hybrid power plant system configuration is shown in Figure 1.

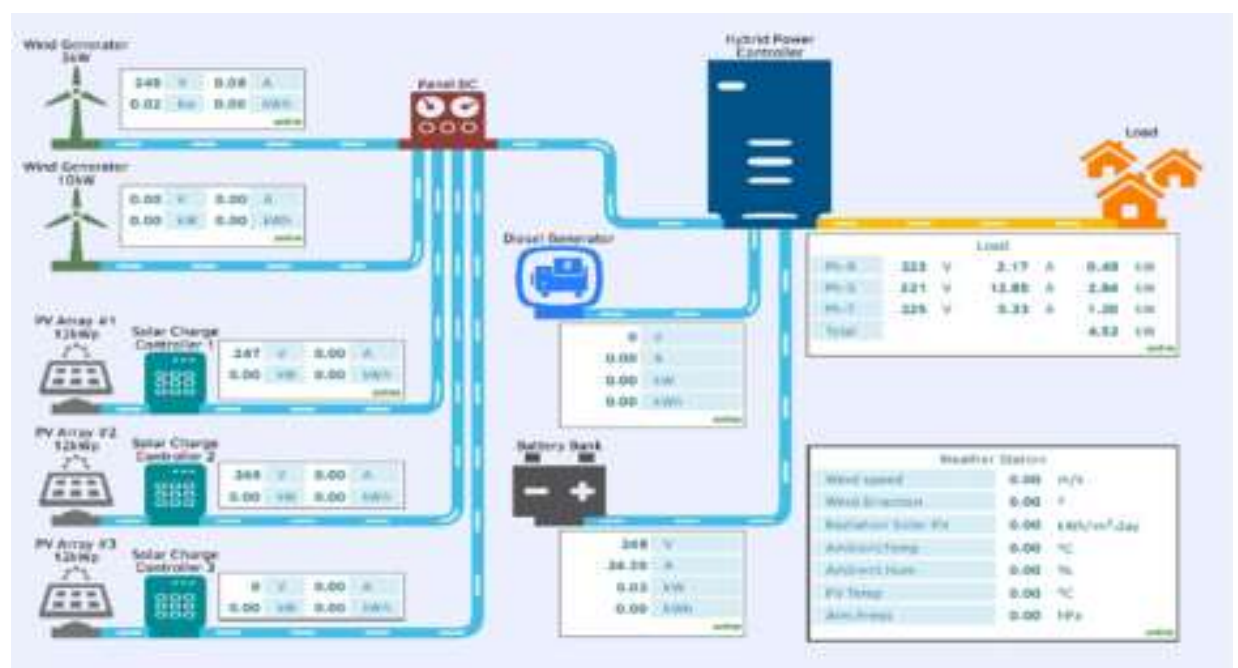

Figure 1. Baron techno park power plant system

\section{Research Method}

Research on the analysis of hybrid power plants with the help of HOMER software has been widely practiced in several countries including Indonesia. Therefore, HOMER feasibility levels can be used to analyzing stand alone and hybrid power generation systems. In this study, used HOMER software for simulation of PLTH Baron Techno Park with two different conditions. The first simulation an off-grid system condition. That modeling was done to known the performance of PLTH in fulfilling internal load (electric energy consumption for main building, electronic device, and location lighting of Baron Techno Park). With the HOMER software, the NPC and COE values are calculated as system performance parameters in meeting the electrical load. The second modeled are on-grid system. That modeled aims to determine the improvement of PLTH performance in the future with the grid in economic terms.

\subsection{Load Profile}

The main daily load of Baron Techno Park is divided into three blocks, R, S, and T. From the results of historical data, known that electrical load in each block are: block $\mathrm{R} 0.78 \mathrm{~kW}$, block $\mathrm{S} 1,542 \mathrm{~kW}$, and block T 1,241 kW. Average total power load is 3,563 kW. Figure 2 shows the electrical load in each block. For daily load profile can be seen in Figure 3. 


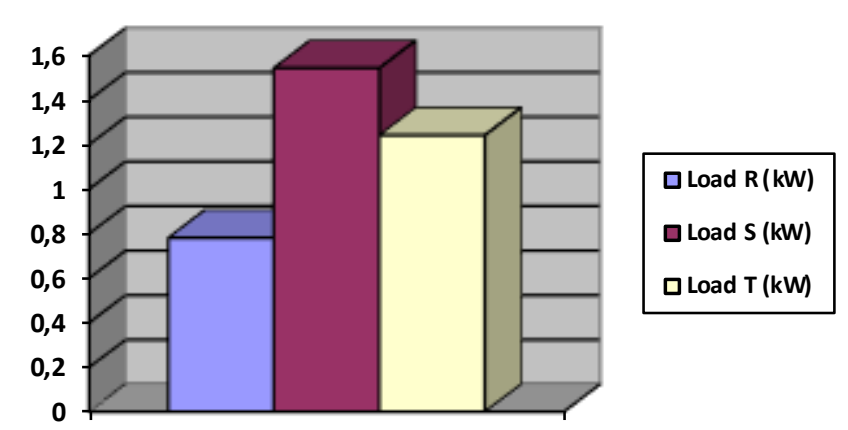

Figure 2. Power loads each Block

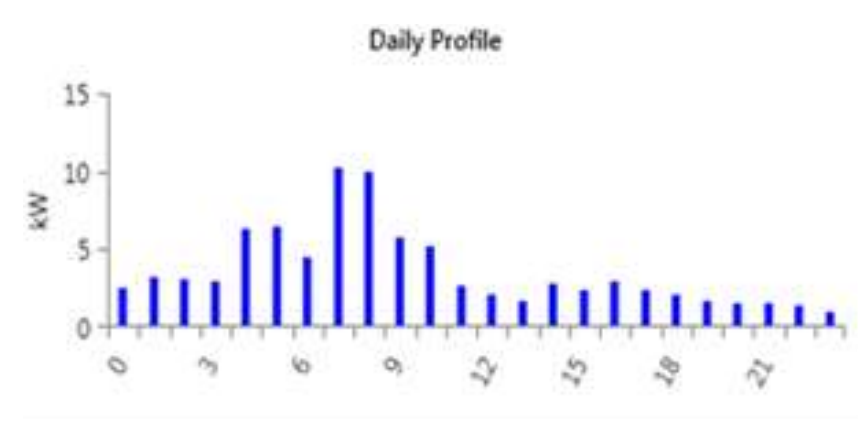

Figure 3. Daily load profile

\subsection{Potential of Wind Energy}

Based on data obtained from NASA, the average speed of wind is $4: 42 \mathrm{~m} / \mathrm{s}$ measured at a height of $50 \mathrm{~m}$. The highest wind speeds are $6: 15 \mathrm{~m} / \mathrm{s}$ in the month of August, while the lowest wind speed is $2.91 \mathrm{~m} / \mathrm{s}$. in December. Figures 4 and Figure 5 shown the average wind speed at the location Baron Techno Park for one year.

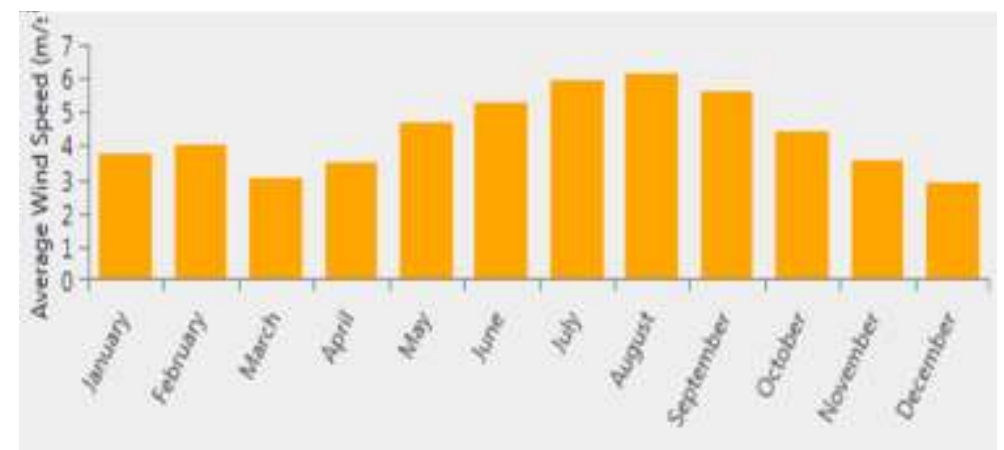

Figure 4. Wind speed (monthly average).

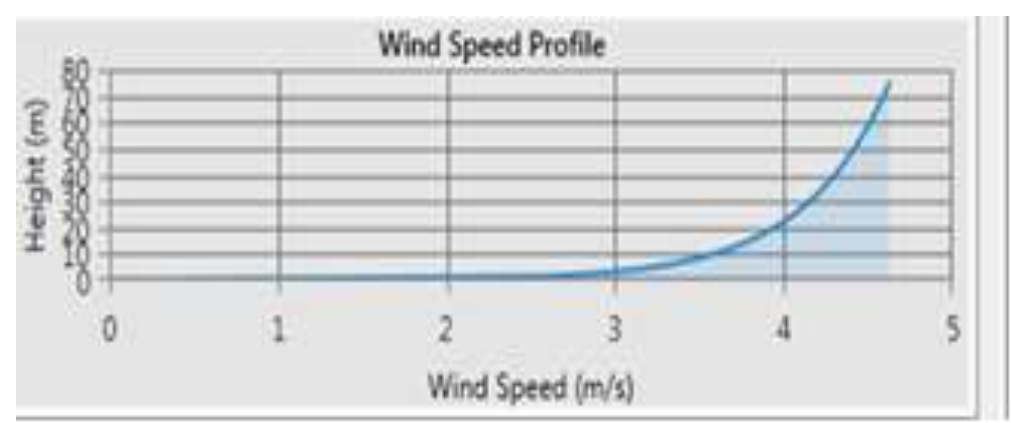

Figure 5. The relation between wind speed and anemometer height. 


\subsection{Solar Energy}

In this study, the monthly solar radiation data were taken from NASA (National Aeronautics and Space Administration). The highest solar radiation obtained in September is $6.56 \mathrm{kWh} / \mathrm{m2} /$ day with clearness index of 0.646 , while the lowest solar radiation is $5.08 \mathrm{kWh} / \mathrm{m} 2 /$ day in January with clearness index of 0.469 . The average solar radiation for one year is $5.66 \mathrm{kWh} / \mathrm{m} 2$ / day. Solar radiation for the location of Baron Techno Park was shown in Figure 6.

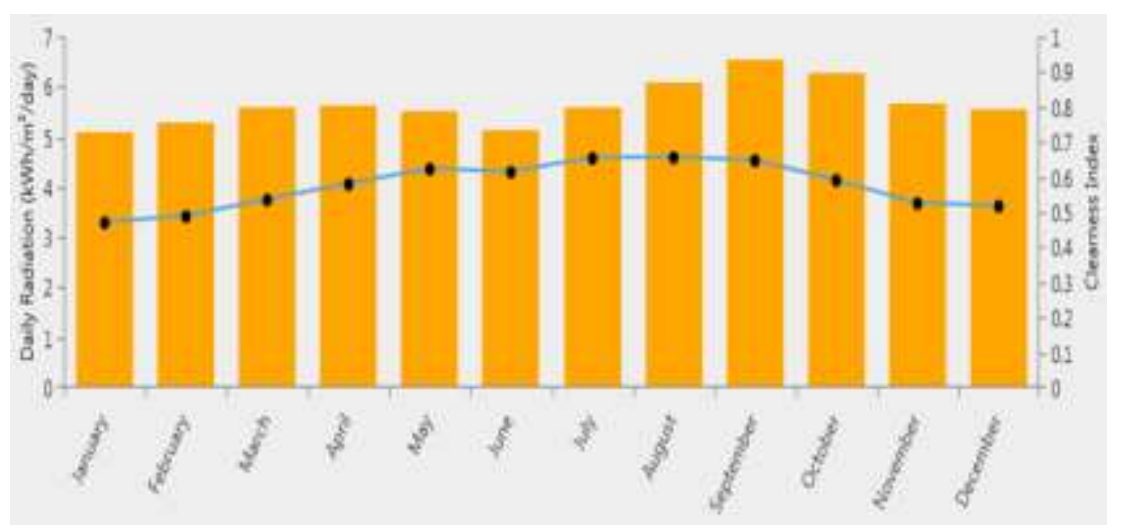

Figure 6. Total solar irradiance and clearness index

Table 1. Solar radiation (SR) and a clearness index (Cl)

\begin{tabular}{lll}
\hline Month & $\mathrm{Cl}$ & $\begin{array}{l}\mathrm{SR} \\
\mathrm{kWh} / \mathrm{m}^{2}\end{array}$ \\
\hline January & 0.469 & 5.080 \\
\hline February & 0.487 & 5.280 \\
\hline March & 0.534 & 5.610 \\
\hline April & 0.579 & 5.630 \\
\hline Mei & 0.622 & 5.500 \\
\hline June & 0.613 & 5.120 \\
\hline July & 0.653 & 5.580 \\
\hline August & 0.655 & 6.090 \\
\hline September & 0.646 & 5.650 \\
\hline October & 0.590 & 6.290 \\
\hline November & 0.524 & 5.650 \\
\hline December & 0.516 & 5.650 \\
\hline
\end{tabular}

\subsection{Hybrid System Components}

A hybrid energy system usually consists of two or more renewable energy sources used at the same time to provide Inserted: and efficiency increased of the system as well as greater balance in energy supply [7]. Capital cost: total cost of the installation of the installed components on the starts of the project. Replacement cost: the cost of replacement component at the end of its useful life, determined by the parameters or specification of component life. Cost of operation and maintenance $(\mathrm{O} \& \mathrm{M})$ : annual fee for operation and maintenance of the system [8].

All those costs required for system modeling. Modeling will be done in two capacities of different hybrid power plant based on a system with an installed capacity of wind power plant with capacity of $15 \mathrm{~kW}$ and solar power with capacity of $36 \mathrm{~kW}$, while the second modeling for systems that currently operating is wind power with a capacity of $5 \mathrm{~kW}$ and solar power with a capacity of $24 \mathrm{~kW}$. Data modeling of hybrid power plant Baron Techno Park consists of solar panels (PV), wind turbines (WG), Battery (BAT), and inverter (INV). Economically data from hybrid power plant Baron Techno Park consists of the initial cost /capital (M), replacement cost (R), the cost of operation and maintenance (O \& M). Technical and economic data are shown in Table 2. 
Table 2. Technical and Economic Data

\begin{tabular}{|c|c|c|c|c|c|}
\hline \multicolumn{3}{|c|}{ Componets } & \multicolumn{3}{|c|}{ Cost } \\
\hline Name & $\begin{array}{c}\text { Capacity } \\
\text { (kW) }\end{array}$ & $\begin{array}{l}\mathrm{L} \\
(\mathrm{yr})\end{array}$ & $\begin{array}{l}M \\
(\$)\end{array}$ & $\begin{array}{c}\mathrm{R} \\
(\$)\end{array}$ & $\begin{array}{c}\text { O \& M } \\
(\$) / \text { years }\end{array}$ \\
\hline PV & 36 & 25 & 135.338 & 2.706 & 436 \\
\hline & 5 & 10 & 6.015 & 120 & 150 \\
\hline WG & 10 & 10 & 9.210 & 184 & 150 \\
\hline BATT & - & 20 & 120.000 & 2.400 & 270 \\
\hline INV & 25 & 8 & 3.945 & 120 & 79 \\
\hline
\end{tabular}

1 \$ = Rp. $13.300,00$

Grid and Emission: Grid is an electricity network provider of PT PLN (Persero), for an interconnection system with the grid, the amount of electrical energy that can be produced by the system or excess of electric power by hybrid power plant system will be purchased by the grid. The mechanism to do will contracts $\mathrm{kWh}$. The price of electricity that must be purchased by the grid of hybrid power plant amounted to the US $\$ 0.091$. The purchase price of electricity from the grid by customers was the US $\$ 0.122$, according to the tariffs applied by the Government [9]. Limits of carbon dioxide were allowed to the grid is 0.714 tons / MWh [10].

\subsection{Modeling and Simulation}

Because the damage on some equipment of Baron Techno Park hybrid power plant like solar panels and wind turbines, the operated system until now is different from the real system plan at the beginning. Initial design system was solar power with power $36 \mathrm{~kW}$ and wind turbines with $15 \mathrm{~kW}$ of power, while the system that operating now are shown in table 2 . Therefore, the modeling and simulation need to be done in the initial design of the real system and operating system. This modeling is done for off grid condition of the system and on-grid conditions.

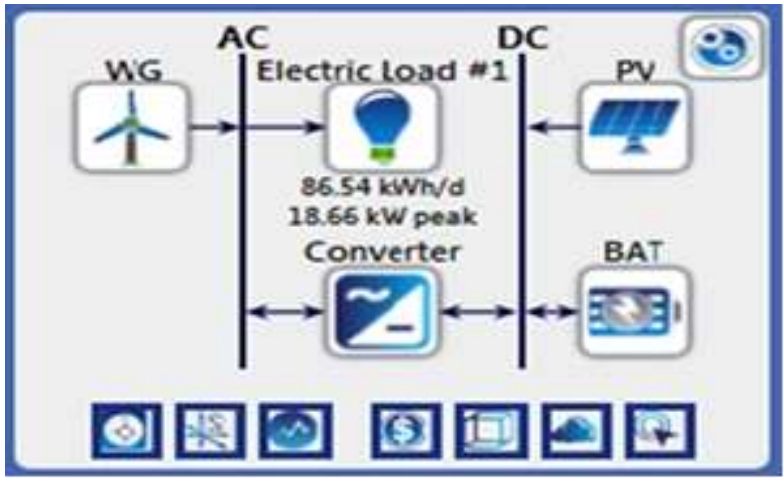

Figure 7. Off-grid Systems

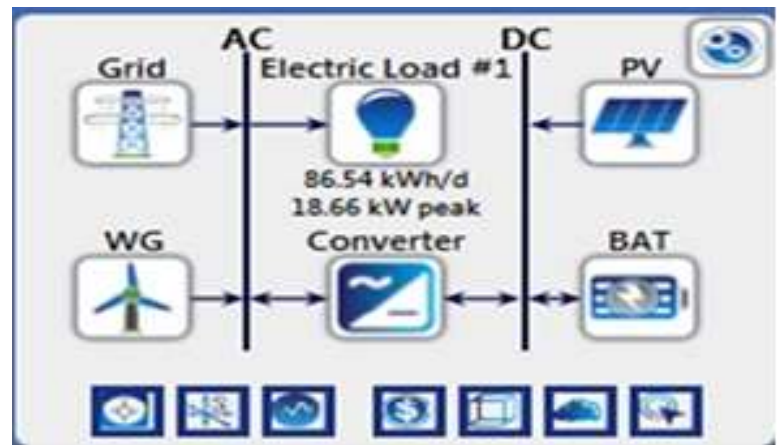

Figure 8. On-grid system 


\section{Results and Analysis} known:

Based on the results of the modeling and analysis that was done by the HOMER program,

\subsection{Hybrid Power Plant System Installed Capacity Off-grid Conditions}

HOMER modeling results and analysis for hybrid power plant system with an installed capacity of NPC obtained for $\$ 196.399$ and COE of $\$ 1.24$, with operating costs of $\$ 15.038$ / year. The production of electric energy amounted to $167.482 \mathrm{kWh} /$ year with a contribution of solar panels at $60.165 \mathrm{kWh} /$ year (35.92\%) and wind turbines amounted to $107.317 \mathrm{kWh} /$ year $(64.08 \%)$. The power consumption of $12.212 \mathrm{kWh} /$ year $(7.6 \%)$. Energy Excess generated of hybrid power plant Baron Techno Park is $154.831 \mathrm{kWh} /$ year (92.4\%). Baron Techno Park hybrid power plant modeling results are shown in Table 3.

Table 3. Results HOMER modeling for a system installed capacity by off-grid conditions.

\begin{tabular}{cccccccc}
\hline $\begin{array}{c}\text { PV } \\
(\mathrm{kW})\end{array}$ & $\begin{array}{c}\text { WG } \\
(\mathrm{kW})\end{array}$ & BAT & $\begin{array}{c}\text { Converter } \\
(\mathrm{kW})\end{array}$ & Dispatch & $\begin{array}{c}\text { COE } \\
(\$)\end{array}$ & $\begin{array}{c}\text { NPC } \\
(\$)\end{array}$ & $\begin{array}{c}\text { Operating } \\
\text { Cost } \\
(\$)\end{array}$ \\
\hline 36.0 & 15 & 24 & 25.0 & CC & 1.24 & 196.399 & 15.038 \\
\hline 36.0 & 15 & 24 & 25.0 & CC & 1.24 & 196.399 & 15.038 \\
\hline 36.0 & 15 & 24 & 25.0 & CC & 1.24 & 196.399 & 15.038 \\
\hline 36.0 & 15 & 24 & 25.0 & CC & 1.24 & 196.399 & 15.038 \\
\hline 36.0 & 15 & 24 & 25.0 & LF & 1.24 & 196.399 & 15.038 \\
\hline 36.0 & 15 & 24 & 25.0 & LF & 1.24 & 196.399 & 15.038 \\
\hline 36.0 & 15 & 24 & 25.0 & LF & 1.24 & 196.399 & 15.038 \\
\hline 36.0 & 15 & 24 & 25.0 & LF & 1.24 & 196.399 & 15.038 \\
\hline 36.0 & 15 & 24 & 25.0 & LF & 1.24 & 196.399 & 15.038 \\
\hline 36.0 & 15 & 24 & 25.0 & LF & 1.24 & 196.399 & 15.038 \\
\hline 36.0 & 15 & 24 & 25.0 & CC & 1.24 & 196.399 & 15.038 \\
\hline 36.0 & 15 & 24 & 25.0 & CC & 1.24 & 196.399 & 15.038 \\
\hline 36.0 & 15 & 24 & 25.0 & LF & 1.24 & 203.096 & 15.542 \\
\hline
\end{tabular}

\subsection{Hybrid Power Plant System that Operats at Off-grid Condition}

Baron Techno Park hybrid power plant system that operated, with off-grid conditions, needs NPC obtained of $\$ 88.493$ and COE of $\$ 0561$ to the operational cost of $\$ 6.760$ / year. Whereas the result of electricity production amounted to $75.882 \mathrm{kWh} /$ year with contributions of solar panels at $40.110 \mathrm{kWh} /$ year (52.86\%) and wind turbines amounted to $35.772 \mathrm{kWh} /$ year (47.14). Electricity Consumption of Baron Techno Park hybrid power plant system only $17 \%$ of the total energy produced or $12.209 \mathrm{kWh} /$ year. The excess of electrical energy produced by Baron Techno Park hybrid power plant of $63.072 \mathrm{kWh} /$ year (83.1\%). Modeling results of Baron Techno Park hybrid power plant shown in Table 4.

Table 4. HOMER modeling results for the system operating with off-grid conditions

\begin{tabular}{cccccccc}
\hline $\begin{array}{c}\text { PV } \\
(\mathrm{kW})\end{array}$ & $\begin{array}{c}\text { WG } \\
(\mathrm{kW})\end{array}$ & BAT & $\begin{array}{c}\text { Converter } \\
(\mathrm{kW})\end{array}$ & Dispatch & $\begin{array}{c}\text { COE } \\
(\$)\end{array}$ & $\begin{array}{c}\text { NPC } \\
(\$)\end{array}$ & $\begin{array}{c}\text { Operating } \\
\text { Cost } \\
(\$)\end{array}$ \\
\hline 36.0 & 5 & 24 & 25.0 & CC & 0.561 & 88.493 & 6.670 \\
\hline 36.0 & 5 & 24 & 25.0 & CC & 0.561 & 88.493 & 6.670 \\
\hline 36.0 & 5 & 24 & 25.0 & CC & 0.561 & 88.493 & 6.670 \\
\hline 36.0 & 5 & 24 & 25.0 & CC & 0.561 & 88.493 & 6.670 \\
\hline 36.0 & 5 & 24 & 25.0 & LF & 0.561 & 88.493 & 6.670 \\
\hline 36.0 & 5 & 24 & 25.0 & LF & 0.561 & 88.493 & 6.670 \\
\hline 36.0 & 5 & 24 & 25.0 & LF & 0.561 & 88.493 & 6.670 \\
\hline 36.0 & 5 & 24 & 25.0 & LF & 0.561 & 88.493 & 6.670 \\
\hline 36.0 & 5 & 24 & 25.0 & LF & 0.561 & 88.493 & 6.670 \\
\hline 36.0 & 5 & 24 & 25.0 & LF & 0.561 & 88.493 & 6.670 \\
\hline
\end{tabular}


Jurnal IImu Teknik Elektro Komputer dan Informatika (JITEKI)

Vol. 3, No. 2, Desember 2017

\begin{tabular}{llllllll}
\hline 36.0 & 5 & 24 & 25.0 & CC & 0.561 & 88.493 & 6.670 \\
\hline 36.0 & 5 & 24 & 25.0 & CC & 0.561 & 88.493 & 6.670 \\
\hline 36.0 & 5 & 24 & 25.0 & LF & 0.561 & 88.493 & 6.670 \\
\hline
\end{tabular}

\subsection{Hybrid Power Plant System Installed Capacity with On-grid Conditions}

Based on the HOMER simulation results for on-grid conditions system with an installed capacity of NPC obtained to $\$ 62.020$ and COE is - $\$ 0.02913$ with operating costs of $\$ 4,910.37$. With an installed grid for the capacity of the system, the excess of energy that was generated by the system can be distributed amounts to $154.831 \mathrm{kWh} /$ year of the total produced energy by the system amounted to $168.842 \mathrm{kWh} /$ year. From the result of the HOMER simulation for on-grid condition known solar power generated energy its production was $60.165 \mathrm{kWh} /$ year $(35.63 \%)$, the contribution of wind turbines amounted to $107.317 \mathrm{kWh} /$ year $(63.56 \%)$, while the production of the grid (grid purchases) is $1,360 \mathrm{kWh} /$ year $(0.81 \%)$. For energy consumption to the conditions known on-grid system is $12.213 \mathrm{kWh} /$ year $(7: 42 \%)$. Sales of electricity to the grid network amounted to $152.473 \mathrm{kWh} /$ year.

Table 5. HOMER modeling results for a system with the installed capacity on-grid conditions.

\begin{tabular}{ccccccccc}
\hline $\begin{array}{c}\text { PV } \\
(\mathrm{kw})\end{array}$ & $\begin{array}{c}\text { WG } \\
(\mathrm{kW})\end{array}$ & BAT & $\begin{array}{c}\text { Grid } \\
(\mathrm{Kw})\end{array}$ & $\begin{array}{c}\text { Converter } \\
(\mathrm{kW})\end{array}$ & Dispatch & $\begin{array}{c}\mathrm{COE} \\
(\$)\end{array}$ & $\begin{array}{c}\text { NPC } \\
(\$)\end{array}$ & $\begin{array}{c}\text { Operating } \\
\text { Cost } \\
(\$)\end{array}$ \\
\hline 36.0 & 15 & 8 & 999,999 & 25.0 & $\mathrm{CC}$ & -0.0260 & -55.032 & -4.384 \\
\hline 36.0 & 15 & 8 & 999.999 & 25.0 & LF & -0.0243 & -51.470 & -4.108 \\
\hline 36.0 & 15 & 16 & 999.999 & 25.0 & CC & -0.0229 & -48.269 & -3.874 \\
\hline 36.0 & 15 & 24 & 999.999 & 25.0 & CC & -0.0197 & -41.566 & -3.370 \\
\hline 36.0 & 15 & 16 & 999.999 & 25.0 & LF & -0.0195 & -41.216 & -3.329 \\
\hline 36.0 & 15 & 24 & 999.999 & 25.0 & LF & -0.0148 & -31.174 & -2.566 \\
\hline 36.0 & 15 & 48 & 999.999 & 25.0 & CC & -0.0102 & -21.464 & -1.856 \\
\hline 36.0 & 15 & 48 & 999.999 & 25.0 & LF & -0.0004 & -839.18 & -260.8 \\
\hline 36.0 & 15 & 96 & 999.999 & 25.0 & CC & 0.00864 & 18.393 & 1.144 \\
\hline 36.0 & 15 & 96 & 999.999 & 25.0 & LF & 0.282 & 57.111 & 4.139 \\
\hline 36.0 & 15 & 192 & 999.999 & 25.0 & CC & 0.0464 & 98.829 & 7.200 \\
\hline 36.0 & 15 & 192 & 999.999 & 25.0 & LF & 0.0839 & 152.039 & 11.316 \\
\hline 36.0 & 15 & 392 & 999.999 & 25.0 & CC & 0.127 & 267.296 & 19.886 \\
\hline
\end{tabular}

\subsection{Hybrid Power Plant System that Operates With On-grid Conditions}

Modeling and analysis for Power Hybrid system with operating capacity for on-grid conditions NPC obtained to $\$ 20,887.76$ and COE - $\$ 0.02132$ with operating costs of $\$ 1,658.87$. For the systems with a capacity of operating of on-grid conditions obtained total energy production amounted to $77.768 \mathrm{kWh}$ / year. The electricity that generated from Solar Power System is 40.110 $\mathrm{kWh} /$ year (51.58\%), on-grid.

Modeling and analysis of hybrid for the power generation system with a capacity of operating conditions for on-grid conditions NPC obtained for $\$ 20,887.76$ and COE - $\$ 0.02132$ with operating costs of $\$ 1,658.87$. Total energy production amounted to $77.768 \mathrm{kWh} /$ year. Electrical energy that's generated by solar panels was being $40.110 \mathrm{kWh} /$ year $(51.58 \%)$, while wind turbines generate electricity at $35.772 \mathrm{kWh} /$ year $(46 \%)$, and production of a grid of $1,886 \mathrm{kWh} /$ year $(2: 42 \%)$. The power consumption of this system amounted to $12.213 \mathrm{kWh} /$ year $(16: 12 \%)$. Therefore, electricity that was sold out from the total excess electrical energy is $63.55 \mathrm{kWh}$ / year.

Table 6. Results HOMER modeling of a system that operates with on-grid conditions

\begin{tabular}{ccccccccc}
\hline $\begin{array}{c}\text { PV } \\
(\mathrm{kw})\end{array}$ & $\begin{array}{c}\text { WG } \\
(\mathrm{kW})\end{array}$ & BAT & $\begin{array}{c}\text { Grid } \\
(\mathrm{Kw})\end{array}$ & $\begin{array}{c}\text { Converter } \\
(\mathrm{kW})\end{array}$ & Dispatch & $\begin{array}{c}\text { COE } \\
(\$)\end{array}$ & $\begin{array}{c}\text { NPC } \\
(\$)\end{array}$ & $\begin{array}{c}\text { Operating } \\
\text { Cost } \\
(\$)\end{array}$ \\
\hline 24 & 5 & 8 & 999,999 & 25.0 & CC & -0.141 & -13.513 & -1.103 \\
\hline 24 & 5 & 8 & 999.999 & 25.0 & LF & -0.0109 & -10.252 & -871.86 \\
\hline
\end{tabular}

Performance Analysis of Hybrid Power Plant (Wind and Solar) in Baron Techno Park Gunung Kidul Yogyakarta (M. G. Pae) 


\begin{tabular}{ccccccccc}
\hline 24 & 5 & 16 & 999.999 & 25.0 & CC & -0.0076 & -7.487 & -649.98 \\
\hline 24 & 5 & 16 & 999.999 & 25.0 & LF & -0.0006 & -647.09 & -121.61 \\
\hline 24 & 5 & 24 & 999.999 & 25.0 & CC & -0.0002 & -225.28 & -102.82 \\
\hline 24 & 5 & 24 & 999.999 & 25.0 & LF & 0.00918 & 8.710 & 588.38 \\
\hline 24 & 5 & 48 & 999.999 & 25.0 & CC & 0.0209 & 19.879 & 1.411 \\
\hline 24 & 5 & 48 & 999.999 & 25.0 & LF & 0.0382 & 35.586 & 2.626 \\
\hline 24 & 5 & 96 & 999.999 & 25.0 & CC & 0.0607 & 59.526 & 4.395 \\
\hline 24 & 5 & 96 & 999.999 & 25.0 & LF & 0.0862 & 76.918 & 5740 \\
\hline 24 & 5 & 192 & 999.999 & 25.0 & CC & 0.143 & 139.931 & 10.448 \\
\hline 24 & 5 & 192 & 999.999 & 25.0 & LF & 0.178 & 152.930 & 11454 \\
\hline 24 & 5 & 392 & 999.999 & 25.0 & CC & 0.326 & 308.268 & 23.124 \\
\hline
\end{tabular}

\section{Conclusion}

Based on the modeling and performance of analysis conducted by HOMER can be concluded that:

1. The Baron Techno Park average electrical load is $12.213 \mathrm{~kW} /$ year consisting of three blocks.

2. For systems with an installed capacity or operating system capable of meeting the electricity needs of Baron Techno Park proved the presence of excess electrical energy generated by the system.

3. Production of energy to the system with the installed capacity is good for both off-grid conditions and on-grid condition, namely $167.482 \mathrm{kWh} /$ year. With an average load consumption of $12.212 \mathrm{kWh}$ / year, the excess electrical energy for this system is $154.831 \mathrm{kWh}$ / year.

4. For off-grid conditions with the system installed capacity NPC and COE value is higher compared to the capacity of the operating system. NPC for the installed system capacity is $\$$ 196.33 and the COE is $\$ 1.24$. while NPC operating system with the capacity now is $\$ 62.020$ and COE - \$0.0213.

5. Improved performance of Baron Techno Park hybrid power generation systems to do with the grid. This is due to distribute electric energy in production, extend the life of the system components, maintain the stability of the electricity needs, and reduce operating costs and maintenance.

6. With the grid, the contribution of Baron Techno Park hybrid power plants can lower carbon dioxide gas amounted to $82.63 \mathrm{~kg} /$ year for operating systems and $202.63 \mathrm{~kg} / \mathrm{year}$ for systems with installed capacity.

\section{References}

[1] N. Mahmud, "System for St Martin Island Using HOMER," 2013.

[2] T. Suhartanto, "Tenaga Hybrid (Angin dan Surya) di Pantai Baru Pandansimo Bantul Yogyakarta," Jnteti, vol. 3, no. 1, pp. 76-82, 2014.

[3] "BPS Provinsi Jawa Tengah."

Accessed from: https://yogyakarta.bps.go.id/linkTableDinamis/view/id/4. 07 April 2017.

[4] "Baron Techno Park." Accessed from: http://btp.b2tke.bppt.go.id/ (07 April 2017)

[5] "PROFIL BARON TECHNO PARK _ ENERGI ALTERNATIF DI YOGYAKARTA 081."

[6] "Monitoring."Accessed

from:http://121.101.132.74/baron/monitoring/index.php?menu=monitoring

[7] U. Sureshkumar, P. S. Manoharan, and A. P. S. Ramalakshmi, "Economic Cost Analysis of Hybrid Renewable Energy System using HOMER,” Sci. Manag., vol. 8, pp. 94-99, 2012.

[8] HOMER Energy, "HOMER Pro Version 3.6 User Manual," no. August, p. 416, 2016.

[9] Esdm, "Permen Esdm 4 Tahun 2012 Tentang Harga Pembelian Tenaga Listrik Oleh Pt.PIn Dari Pembangkit Tenaga Listrik Yang Menggunakan Energi Terbarukan Skala Kecil Dan Menengah Atau Kelebihan Tenaga Listrik," 2012.

[10] Badan Perencanaan Pembangunan Nasional, "Pedoman Penyusunan Rencana Aksi Daerah Penurunan Emisi Gas Rumah Kaca," pp. 1-160, 2011. 